\title{
EVALUATION OF SUSCEPTIBILITY TO INJURIES RESULTING FROM FALLS OF CHILDREN WITH VISUAL IMPAIRMENT
}

\author{
Dariusz Boguszewski ${ }^{1}$, Martyna Zabłocka ${ }^{2}$, Jakub Grzegorz Adamczyk ${ }^{1,3}$, \\ Katarzyna Boguszewska ${ }^{4}$, Dariusz Białoszewski ${ }^{1}$ \\ 1. Rehabilitation Department. Medical University of Warsaw, Poland \\ 2. Students Science Club of Physiotherapy. Medical University of Warsaw, Poland \\ 3. Theory of Sport Department. University of Physical Education in Warsaw, Poland \\ 4. Piotr Skarga Catholic Educational Center in Warsaw, Poland
}

The main purpose of the study was the analysis of safe falling skills visually impaired children. An attempt has been made to examine the relationship between ability of safe falls and occurrence injuries from the effect of falls. 103 children (10-16 years old) were in research and control groups. In the research group (Group I) was 39 visually impaired pupils, in control group (Group II) 64 sighted in a proper manner. Test of Susceptibility to Injury During the Falls (TSIDF) by Kalina and interview directed to determine the number and frequency of falls and their consequences were used as a research tools. There were 578 falls and 176 injuries resulting from them ( 7.33 falls per person in Group I and 4.96 in Group II; 2.51 injuries per person in Group I and 1.18 in Group II). Visually impaired people made more mistakes in test (TSIDF) than their non-disabled peers $(p=0.007)$. This may prove that a high susceptibility to injury of the children from the research group $(\mathrm{p}=0.001)$. However visual impairment people had more injuries after the falls. Study confirmed positive effect of physical activity on the level of safe falls skills. The ability to fall down in a safe way in children suffering from visual impairment is more improperly developed when compared it to healthy children. Physical activity and especially exercises of safe falls skills can be important element of prevention of falls.

Key words: falls, susceptibility to injury, visually impaired people, disabled children

\section{INTRODUCTION}

Sense organs are our "primary channels" in receiving stimuli from the environment. Sight is seemingly the most important sense for every human being. However, it is particularly important for children who learn the world through knowing the objects and phenomena surrounding it (Gruszczyński \& Rutkowska, 2003). Therefore, considerable impairment or complete loss of sight has great impact on the child's cognitive abilities, even though it does not change the child's potential developmental possibilities (Rutkowska, MorgulecAdamowicz, Skowroński, 2009).

Similarly to people undergoing limb amputation, suffering from osteoporosis or musculoskeletal system conditions, children suffering from visual impairment (VI) are a group which is particularly prone to injuries resulting from falls (Kalina, Kalina \& Klukowski, 1998). In this case, falls are considered to be social problems, since to a large extent they are the primary causes of serious injuries, or even death. It is therefore vital to create a set of principles helping the avoid situations which may potentially result in falls and to implement a prophylactic study of body movements which could minimize the harmful effects of collapsing to the ground or hitting a vertical obstacle (Kalina, Kalina \& Klukowski, 1998).

Scientific research has proven that a falling persons have not the skills to secure themselves. This was the reason to develop the safe fall theory (Czerwiński et al., 2006; Kalina et al., 2003, 2011). The safe fall theory states the measures to be taken in order to completely avoid or mitigate the effects of injuries resulting from threatening situations. It should be noted that specialists in dangerous professions, affecting the falls and injuries (such as stuntmen, athletes or soldiers of the special units) the ability to the safe falling down use in everyday real life. Hence, the people who tend to fall down and suffer from 
severe injuries resulting from the falls (occurring in the street, at home, on stairs, etc.) are usually those who do not possess the ability or knowledge of falling down safely (Kalina, Kalina \& Klukowski, 1998; Boguszewski \& Kerbaum, 2011).

Therefore, in order to reduce the risk of suffering from post-fall injuries, one should develop the habit of falling down in a safe way. Motor coordination, the ability to protect one's head, the ability to loosen one's muscles all contribute to preventing body injuries during falls. Such elements could reduce the risk entailed by falls or resulting personal injuries (Kalina et al., 2003, 2011; Boguszewski \& Kerbaum, 2011). People with visual impairment are particularly prone to injuries resulting from falls (Coleman et al.; 2004, Black \& Wood, 2005; Patino et al., 2010; Manduchi \& Kurniawan, 2011). Therefore, a special preventive program dedicated entirely to the visually impaired could reduce the risk of life-threatening injuries. Similar solutions have been used with positive results among different groups (e.g. the elderly) (Rubenstein, et al., 2000; Barnett, et al., 2003; Li, et al., 2005; Rose, 2008; Groen et al., 2010).

The aim of the study was the diagnosis of safe falling skills visually impaired children and their healthy peers. An attempt has been made to:

1. Establish the relationship between the skills to safely falling down and the occurrence of injuries resulting from falls.
2. Determine the relationship between physical activity and susceptibility to injury during falls.

\section{METHODS}

\section{Participants}

The research covered a group of 103 children between the age of 10 and 16 (including 43 girls and 60 boys). The children participating in the research were divided into two groups - the researched group $(n=39)$ comprised children with visual impairment (VI) - Group I, and the control group $(n=64)$ of children without visual impairment - Group II (table 1). The average age of children participating in the research was 13.1. There were not significant differences between groups in age, body mass and height. The WHO classification was applied in reference to the researched group. According to the WHO classification, the children were diagnosed with visual impairment - best corrected visual acuity was from 0.3 to 0.005 in the better eye. Additionally, only children without any other dysfunctions (e.g. neurological dysfunctions) which could potentially inhibit their motor abilities have been qualified for the research.

The research was carried out in the 2010/2011 school year in the Educational Center for Children with Visual Impairment in Warsaw (Group I) and in the public school in Warsaw (Group II).

TABLE 1

Characteristics of research groups (mean value \pm standard deviation)

\begin{tabular}{|c|c|c|c|c|c|c|}
\hline groups & gender & $\mathrm{n}$ & age [years] & body mass [kg] & height [cm] & $\begin{array}{c}\text { physically } \\
\text { active [n] }\end{array}$ \\
\hline \multirow{2}{*}{$\begin{array}{c}\text { Group I } \\
\text { (visual impaired) }\end{array}$} & girls & 15 & $12.4 \pm 1.5$ & $45.8 \pm 9.9$ & $154.9 \pm 10.3$ & 5 \\
\cline { 2 - 7 } Group II (control) & boys & 24 & $13.8 \pm 2.1$ & $60.2 \pm 12.1$ & $168.5 \pm 11.1$ & 13 \\
\cline { 2 - 7 } & girls & 28 & $12.4 \pm 2.1$ & $46.6 \pm 10.3$ & $156.1 \pm 8.9$ & 14 \\
\hline
\end{tabular}




\section{MEASURES AND PROCEDURES}

One of the tools used in the research was Kalina's Test of Susceptibility to Injury During the Falls (TSIDF). Reliability of the test was confirmed by the author (for groups of healthy young people) (Kalina et al., 2011). The test was based on performing three motor activities as fast as possible. The first motor activity was proceeding from the basic position to lying down on the back (on a mattress). In the second motor activity, apart from the above mentioned process, the child had to hold a small bag between the chin and the sternum and to clap its knees. In the third motor activity, apart from the above mentioned, basic movement, the child was to make a leap before proceeding to lying down on the back. However, children were not specifically instructed how to make the exercises. Each attempt was evaluated for errors - deviations from the correct mode of safe falling. The results were entered to the observation sheet. The sum of errors for particular body parts (head, legs, hips, arms) collected from all three activities serves as the Susceptibility to Injury During the Falls Index (SIDF). The higher the result, the higher was the proneness to injuries. The sum of points collected after all three activities serves as the Susceptibility to Injury During the Falls Index, in which 0 points stands for low proneness, 1 to 3 points stand for medium proneness, 4 to 9 points stand for high proneness, and 10 to 14 points stand for very high proneness (Kalina et al., 2011). All children were assessed by two specialists in physical education and physiotherapy (specializing in teaching safe falling down).

The research was accompanied by an investigation of the types of falls (number of falls, circumstances of occurrence), the injuries incurred during falls (with the exception of sports-related injuries), and the types of physical activities performed (type, frequency). Information from the last three years was included in the investigation.

\section{Data Analysis}

For comparative purposes, two additional divisions into sub-groups have been isolated as part of the above mentioned groups. In the first division into sub-groups, undertaking or nonundertaking regular physical activity was the essential criterion. Children who participated in organized sports or recreational classes minimum three times a week outside their school classes were classified as active (table 1). The second division into sub-groups referred to the age of the researched children younger (10-13 years old) and older children (14-16 years old).

Standard statistical tools, such as arithmetic mean and standard deviation, were applied in the research. The relations between particular variables (number of injuries and results of SIDF Test) were established with the Pearson's correlation coefficient. The differences between particular data were calculated with independent t-test. The minimal significance level was established at $\mathrm{p}<0.05$.

\section{RESULTS}

\section{Test of Susceptibility to Injury During the Falls}

Children from Group I got significantly higher results in the Test of Susceptibility to Injury During the Falls $(p=0.007)$, which means that they committed a larger number of errors performing the motor activities. The biggest disparities $(p=0.004)$ occurred in the last activity, which was theoretically the most difficult one. The majority of errors committed by children from both groups concerned applying improper support with the hands. The biggest disparities between the two groups were recorded in this respect. The smallest disparities (statistically insignificant) were recorded with respect to protection of the head (fig. 1 and 2). The results of the Test of Susceptibility to Injury During the Falls acquired by boys and girls were quite similar.

In Group I almost $82 \%$ of the children were characterized by high or very high proneness to injuries resulting from falls. In comparison, nearly $67 \%$ of children from the control group were similarly classified. In opposition to nonactive children, physically active children committed fewer errors while performing the assigned motor activities, although significant disparities $(p=0.000)$ were recorded only in Group II. Only $5(9 \%)$ of physically active children acquired a result standing for very high proneness to post-fall injuries. 17 (37\%) non-active children acquired the same result. $23(41 \%)$ of physically active children and 5 (11\%) non-active children were characterized by low or medium proneness to post-fall injuries (tab. 2). 


\section{FIGURE 1}

Results of Test of Susceptibility to Injury During the Falls among the girls

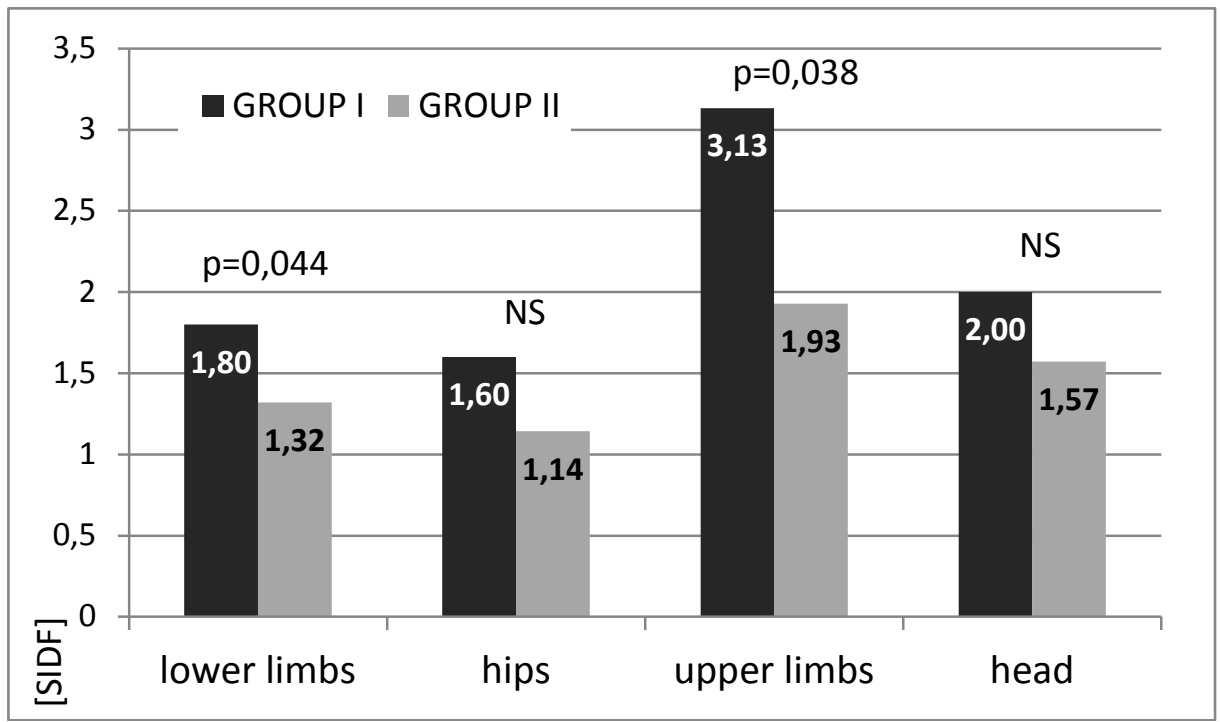

\section{FIGURE 2}

Results of Test of Susceptibility to Injury During the Falls among the boys

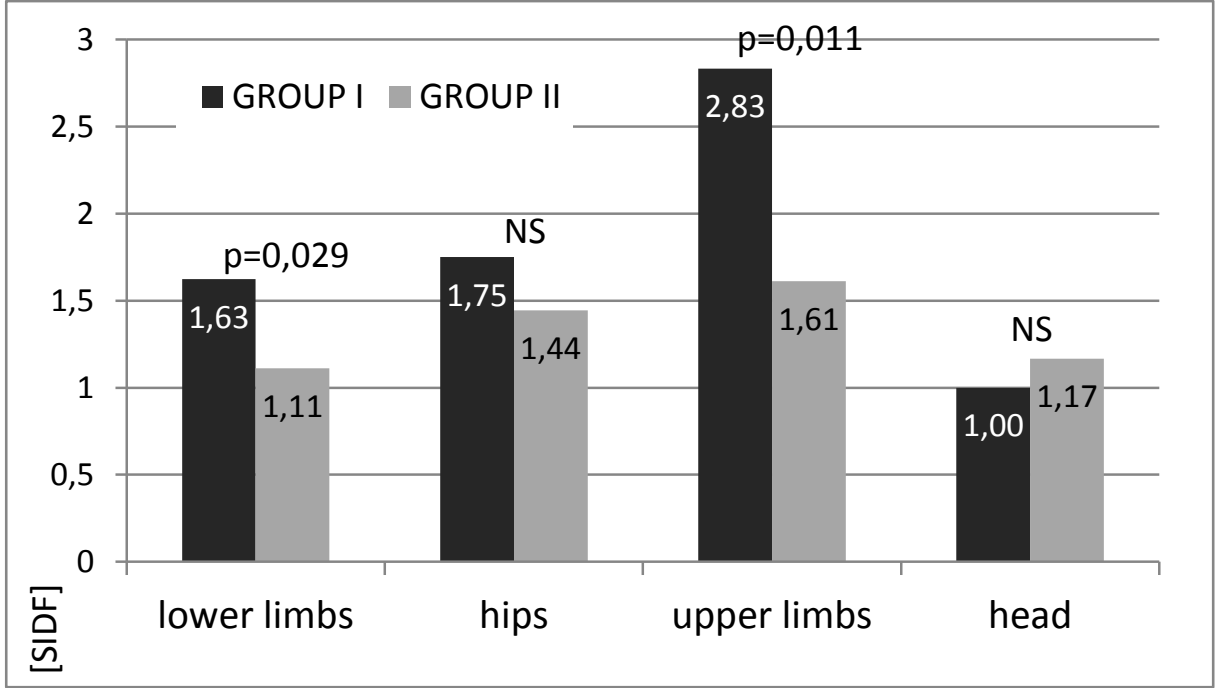

\section{TABLE 2}

Level of susceptibility to injury during a fall of girls and boys

\begin{tabular}{|c|c|c|c|c|c|c|}
\hline \multirow{2}{*}{\multicolumn{2}{|c|}{ groups }} & \multirow{3}{*}{$\begin{array}{c}\text { gender } \\
\text { girls }\end{array}$} & \multicolumn{4}{|c|}{ susceptibility to injury during a fall } \\
\hline & & & \multirow{2}{*}{$\begin{array}{c}\text { low } \\
0\end{array}$} & \multirow{2}{*}{$\frac{\text { average }}{0}$} & \multirow{2}{*}{$\frac{\text { high }}{3}$} & \multirow{2}{*}{$\begin{array}{c}\text { very high } \\
2\end{array}$} \\
\hline \multirow{4}{*}{ Group I } & \multirow{2}{*}{ active } & & & & & \\
\hline & & boys & 1 & 3 & 6 & 3 \\
\hline & \multirow{2}{*}{ non-active } & girls & 0 & 2 & 4 & 4 \\
\hline & & boys & 0 & 1 & 6 & 4 \\
\hline \multirow{4}{*}{ Group II } & \multirow{2}{*}{ active } & girls & 1 & 4 & 9 & 0 \\
\hline & & boys & 1 & 13 & 10 & 0 \\
\hline & \multirow{2}{*}{ non-active } & girls & 0 & 1 & 10 & 3 \\
\hline & & boys & 0 & 1 & 5 & 6 \\
\hline
\end{tabular}


Younger children (between the age of 1013) from both groups acquired a higher result in the Test of Susceptibility to Injury During the Falls, which means that they committed more errors. Bigger disparities concerned boys rather than girls. When it comes to the subgroup of younger children, children with visual impairment committed more errors in all of three assigned motor activities. However, considerable disparities were recorded only in the "arm" category in girls $(\mathrm{p}=0.047)$ and in the "head" category in boys $(p=0.014)$. When it comes to the sub-group of older children (1416 years old), the disparity between handicapped and healthy children were bigger. In particular, boys from Group I displayed a significantly lower level of motor skills in comparison to their peers from Group II. Statistically significant differences were recorded in the "legs" category $(\mathrm{p}=0.000)$, the "arms" category $(\mathrm{p}=0.003)$ and the "head" category $(\mathrm{p}=0.016)$.

\section{Falls and injuries}

The majority of children participating in the research $(88 \%)$ claimed to have fallen at least once in the last three years, $35(90 \%)$ children from group one and $57(89 \%)$ children from group two fell down at least once. In total, the research children declared 578 falls and 176 personal injuries (resulting from the falls). The average number of falls per person in Group I was 7.33, and 4.96 in Group II. Boys tended to fall down more often (in average 7.58 - Group I and 5.64 - Group II) than girls (correspondingly 6.93 and 4.11 ). The average number of personal injuries was 2.51 with respect to handicapped children and 1.18 with respect to healthy children. Girls tended to suffer from personal injuries more often (in average 2.97 - Group I and 1.21 - Group II) than boys (correspondingly 2.41 and 1.16).

Physically active children rarely suffered from post-fall injuries (in average 2.39 per person - Group I and 0.89 - Group II) in comparison to non-active children (correspondingly 2.62 and 1.62). Injuries incurred usually concerned the lower limbs (in average 1.06 per person in reference to nonactive children and 0.62 in reference to active children).

\section{The type and location of injuries}

Visually impaired children suffered from more injuries resulting from collapsing to the ground $(\mathrm{p}=0.001)$. The most common injuries in group one were wounds and abrasions (in average -1.15 per person), however, in group two - these were mainly contusions (0.67). The most severe injuries, such as bone fractures usually occurred in children suffering from visual impairment (in average 0.33 Group I, 0.06 - Group II). Both physically active and non-active children suffered primarily from minor injuries - wounds, abrasions and contusions (slightly more incidents in the non-active group). Bone fractures occurred rarely in both groups. Still the number of fractures was bigger in the nonactive group. The average number personal injuries was nearly identical with girls (1.72) and boys (1.67).

When it comes to children with visual impairment, the injuries were generally located around the lower limb area (in average 1.15 per person) and, slightly rarer, in the upper limb area (1.07). Injuries of the head area or of the spinal area were rather rare $(0.36)$, since these are the body parts which should be particularly protected during a fall. Similar tendency was recorded in the control group, where the majority of injuries concerned the lower limb area (0.62), and the upper limb area (0.41). Head and spine injuries were rare (0.12), even rarer than in the case of the first group (fig. 3 and 4).

Comparison of the number of falls and injuries of children physically active and inactive, and younger and older children

Children with visual impairment staying physically active usually suffered from injuries of the lower limbs (in average 1.2 per person) and of the upper limbs (in average - 1 per person). On the other hand, physically active children from Group II usually suffered from injuries of the lower limbs (0.5). Injuries of the head and spine area were rather rare $(0.28-$ Group I, 0.08 - Group II). Non-active children indicated more injuries of all aforementioned body parts (head and spine: in average $0.43-$ Group I and 0.19 - Group II; upper limbs: 0.91 and 0.61; lower limbs: 1.38 and 0.81 ).

Younger children (10-13 years old) suffered from falls and resulting injuries slightly more often than older children. No significant disparities in the number of falls and resulting injuries were recorded between Groups I and 
II. The above mentioned events referred to children suffering from visual impairment only (tab. 3). When it comes to older children (1416 years old), the disparities (particularly in the number of injuries) were more significant.
Visually impaired girls suffered from post-fall injuries more often $(\mathrm{p}=0.048)$, whereas in the case of boys, the result was close to the significance level ( $\mathrm{p}=0.077)$ (tab. 4).

\section{FIGURE 3}

Number of injuries resulting from the fall of the girls

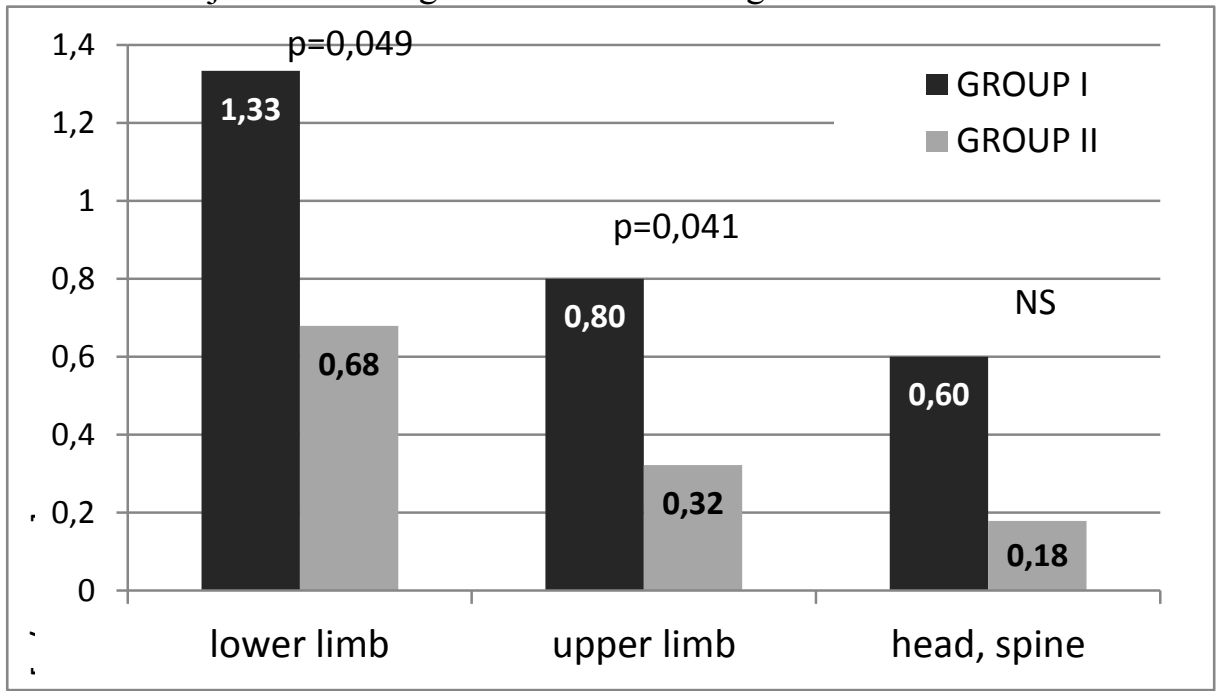

\section{FIGURE 4}

Number of injuries resulting from the fall of the boys

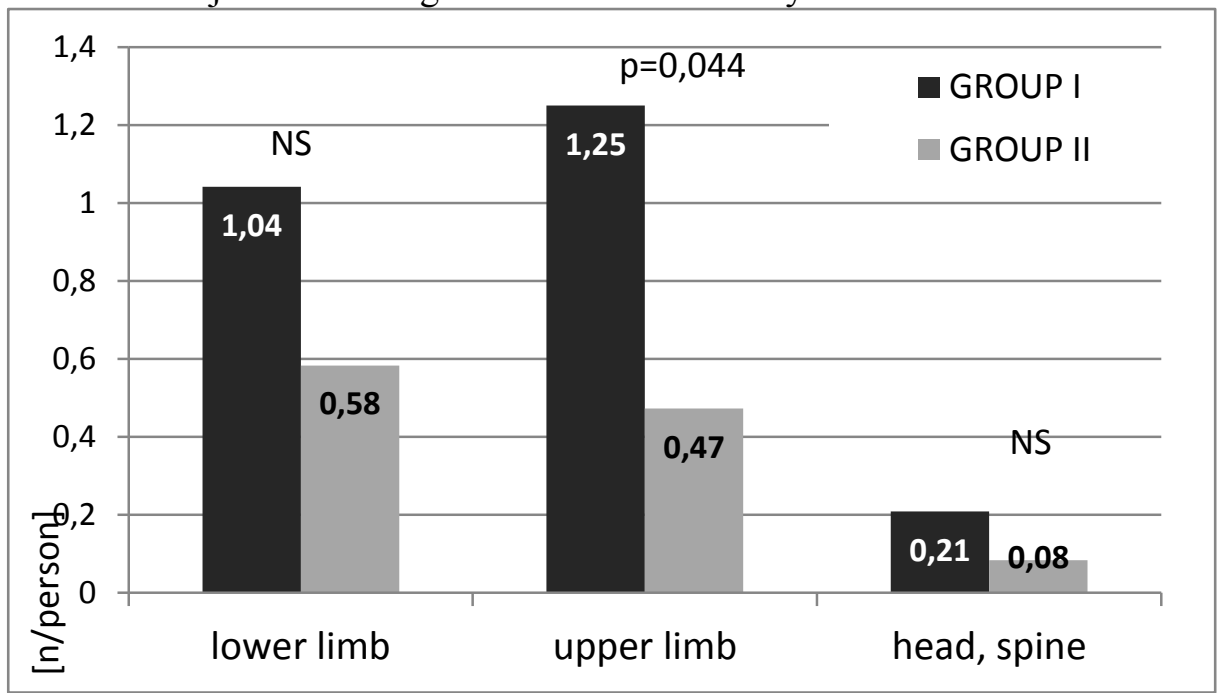

Children who acquired lower results in the Test of Susceptibility to Injury During the Falls declared to have suffered from post-fall injuries more often. The correlation between the Test result and the number of injuries was $\mathrm{r}=0.58 \quad(\mathrm{p}=0.000)$. To a great extent, this tendency concerned children with visual impairment $(\mathrm{r}=0.6 \mathrm{p}=0.000)$ rather than healthy children $(\mathrm{r}=0.53 \mathrm{p}=0.000)$. 
TABLE 3

SIDF indicator value, the number of falls and injuries among the children aged 10-13 years

\begin{tabular}{|c|c|c|c|c|c|c|c|c|c|c|}
\hline & \multicolumn{5}{|c|}{ Girls } & \multicolumn{5}{|c|}{ Boys } \\
\hline & \multicolumn{2}{|c|}{$\begin{array}{c}\text { Group I } \\
(\mathrm{n}=11)\end{array}$} & \multicolumn{2}{|c|}{$\begin{array}{c}\text { Group II } \\
(\mathrm{n}=20)\end{array}$} & \multirow{2}{*}{$\mathrm{p}$} & \multicolumn{2}{|c|}{$\begin{array}{c}\text { Group I } \\
(\mathrm{n}=4)\end{array}$} & \multicolumn{2}{|c|}{$\begin{array}{c}\text { Group II } \\
(\mathrm{n}=19)\end{array}$} & \multirow{2}{*}{$\mathrm{p}$} \\
\hline & $\begin{array}{l}\text { mean } \\
\text { value }\end{array}$ & SD & $\begin{array}{l}\text { mean } \\
\text { value }\end{array}$ & $\mathrm{SD}$ & & $\begin{array}{l}\text { mean } \\
\text { value }\end{array}$ & $\mathrm{SD}$ & $\begin{array}{l}\text { mean } \\
\text { value }\end{array}$ & $\mathrm{SD}$ & \\
\hline SIDF & 8.81 & 3.97 & 6.85 & 2.43 & 0.156 & 6.43 & 2.28 & 7.73 & 3.19 & 0.332 \\
\hline falls & 5.09 & 3.27 & 3.55 & 3.3 & 0.225 & 3.86 & 3.02 & 5.21 & 3.49 & 0.351 \\
\hline injuries & 2.73 & 2.05 & 1.5 & 0.83 & 0.082 & 2.71 & 2.29 & 1.32 & 1.11 & 0.164 \\
\hline
\end{tabular}

\section{TABLE 4}

SIDF indicator value, the number of falls and injuries among the children aged 14-16 years

\begin{tabular}{|c|c|c|c|c|c|c|c|c|c|c|}
\hline & \multicolumn{5}{|c|}{ Girls } & \multicolumn{5}{|c|}{ Boys } \\
\hline & \multicolumn{2}{|c|}{$\begin{array}{c}\text { Group I } \\
(\mathrm{n}=7)\end{array}$} & \multicolumn{2}{|c|}{$\begin{array}{c}\text { Group II } \\
(\mathrm{n}=8)\end{array}$} & \multirow{2}{*}{$\mathrm{p}$} & \multicolumn{2}{|c|}{$\begin{array}{c}\text { Group I } \\
(\mathrm{n}=17)\end{array}$} & \multicolumn{2}{|c|}{$\begin{array}{c}\text { Group II } \\
(\mathrm{n}=17)\end{array}$} & \multirow{2}{*}{$\mathrm{p}$} \\
\hline & $\begin{array}{l}\text { mean } \\
\text { value }\end{array}$ & SD & $\begin{array}{l}\text { mean } \\
\text { value }\end{array}$ & SD & & $\begin{array}{l}\text { mean } \\
\text { value }\end{array}$ & SD & $\begin{array}{l}\text { mean } \\
\text { value }\end{array}$ & SD & \\
\hline SIDF & 6.25 & 4.35 & 3.75 & 3.54 & 0.364 & 7.41 & 3.82 & 2.76 & 2.31 & 0.000 \\
\hline falls & 12.5 & 8.69 & 5.5 & 4.84 & 0.209 & 9.12 & 7.86 & 5.12 & 3.87 & 0.072 \\
\hline injuries & 2.5 & 1.29 & 0.5 & 0.53 & 0.048 & 2.29 & 2.66 & 1 & 1.06 & 0.077 \\
\hline
\end{tabular}

\section{DISCUSSION}

People of all ages have and will fall down. This is considered one of the major problems of senior age, and the main cause of injuries in seniors. Nearly $20 \%$ of all causes of death of people over the age of 65 include post-fall injuries (Skalska, Walczewska \& Ocetkiewicz, 2003; Bączkowicz, Szczegielniak \& Proszkowiec, 2008; Czerwiński et al., 2008). The causes of falls include internal conditions (illness, senile conditions) and external conditions (environmental, situational conditions). Preventing falls is thus an essential, but expensive issue. Research clearly shows that it is possible to lower the risk of falls even by $40 \%$ if the patient is treated by a multidisciplinary team (Skalska, Walczewska
\& Ocetkiewicz, 2003; Czerwiński et al., 2008). People who underwent lower limb amputation, people suffering from diabetes, people using wheelchairs, seniors, people suffering from osteoporosis, as well as people suffering from visual impairment are particularly prone to falling (Capella-McDonnal, 2007; Patino et al., 2010; Manduchi \& Kurniawan, 2011; Odom, Odom, Leys, 2011).

Evaluations of proneness to injuries resulting from falls in people with visual impairment have been carried out very rarely. People suffering from complete blindness or partial visual impairment are examined primarily for their physical fitness and posture (Bolach et al., 2007, Bolach, Bolach \& Józefowski, 2009; Patel et al., 2009; Jessup, Cornel \& Bundy, 2010; Rutkowska, 
Bednarczuk, Skowroński, 2010). The occurrence of injuries resulting from falls is generally evaluated in seniors or healthy children, without comparing their results with the results acquired by children suffering from various conditions and dysfunctions (Tinetti \& Williams, 1997; Kalina, Kalina \& Klukowski, 1998; Czerwiński et al. 2008).

Physical fitness may serve as the basis for fall prevention, since it contributes to improving bone structure, influences the operation of the respiratory and circulatory systems, and results in increasing the muscular structure as well as the scope of movement of the joints (Tinetti \& Williams, 1997; Boguszewski \& Kerbaum, 2011). Physical fitness helps us to properly position our bodies in order to fall in a safe manner. Therefore, thanks to physical fitness, we not only become fitter, but we also become less liable to fall down randomly - hence we are less prone to injuries resulting from a fall (Tinetti \& Williams, 1997; Skalska, Walczewska \& Ocetkiewicz, 2003; Skelton, Kennedy \& Rutherford, 2004).

Epidemiological data indicates that the majority of effects of falls in the form of fractures were recorded in two age groups: from 8 to 15 and above 60 (Czerwiński, Borowy \& Jasiak, 2006). However, there is no statistical data defining the types and locations of injuries in people suffering from visual impairment (Kalina, Kalina \& Klukowski, 1998). The results of this research allow us to claim that children between the age of 10 and 16 may be prone to personal injuries resulting from falls, which is proven by high results of the Test of Susceptibility to Injury During the Falls carried out.

The natural direction for further research would be to expand the groups of people covered and to include the cause of the loss of sight as a valid criterion. Due to frequent occurrence of posture defects, it would be justified to include an evaluation of postures in researched groups (Bolach et al., 2007; Bolach, Bolach \& Józefowski, 2009). Additional elements to be diagnosed may be the ability to fall down in a safe manner in all variants of falls occurring in everyday lives - falls to the back, falls to the front and falls to the side). This would help to establish and evaluate selfprotection movements to be applied in all possible situations. Yet another direction for research to be applied should be the diagnosis of proneness to personal injuries resulting from falls after having undergone intense safefalling training, for instance in the form of program based on the propaedeutics of combat sports (Kalina et al., 2008; Gąsienica-Walczak et al., 2010; Boguszewski \& Kerbaum, 2011), in order to claim to what extent the abilities taught are acquired by the trainees and how they could be applied in everyday life.

\section{CONCLUSIONS}

1. The ability to fall down in a safe way in children suffering from visual impairment is more improperly developed when compared it to healthy children. Therefore, children with visual impairment may be more prone to personal injuries resulting from situations ending with falls.

2. Visually impaired children often have injuries from falls. This may be a result of a lower level of special coordination and inability to safe falling. The risk of falls and injuries that may occur can be minimized by learning specific skills (safe fall).

3. The results of research prove the beneficial effect of physical activity on the occurrence of defensive reflexes, protecting the body from being harmed. Children spending their time actively suffered from fewer injuries after falling down than non-active children.

\section{REFERENCES}

Bączkowicz, D., Szczegielniak, J. \& Proszkowiec, M. (2008). Relations between postural stability, gait and falls in elderly persons - preliminary report. Ortopedia Traumatologia Rehabilitacja, 10(5), 476480.

Barnett, A., Smith, B., Lord, S.R., Williams, M. \& Baumand A. (2003). Communitybased group exercise improves balance and reduces falls in at-risk older people: A randomized controlled trial. Age Ageing. 32(4), 407-414.

Black, A. \& Wood, J. (2005). Vision and falls. Clinical and Experimental Optometry, 88, 212-222.

Boguszewski, D. \& Kerbaum, K. (2011). Judo training as a means of reducing susceptibility to injury during falls. Medycyna Sportowa. Polish Journal of Sports Medicine, 27(3), 205-212.

Bolach, B., Bolach, E. \& Józefowski, P. 
(2009). Ocena aktywności ruchowej i postawy ciała u młodzieży niedowidzącej. [Assesment of physical activity and body posture visual imairment adolescent]. Postępy Rehabilitacji, 4, 45-51.

Bolach, E., Barczyk, K., Bolach, B., Sipko, T. \& Skolimowski J. (2007). Evaluation of the influence of ballroom dance upon the posture of blind children. Polish Journal of Physiotherapy, 7(4), 63-70.

Brambring, M. (2006). Divergent Development of Gross Motor Skills in Children Who Are Blind or Sighted. Journal of Visual Impairment \& Blindness, 100, 10, 620-634.

Capella-McDonnal, M. (2007). The Need for Health Promotion for Adults Who Are Visually Impaired. Journal of Visual Impairment \& Blindness, 101, 3, 133-145.

Coleman, A.L., Stone, K., Ewing, S.K., Nevitt, M., Cummings, S. \& Cauley, J.A. (2004). Higher risk of multiple falls among elderly women who lose visual acuity. Ophthalmology 111, 857-862.

Czerwiński, E., Białoszewski, D., Borowy, P., Kumorek, A. \& Białoszewski, A. (2008). Epidemiology, Clinical Significant, Cost and Fall Prevention in Elderly People. Ortopedia Traumatologia Rehabilitacja, 10(5), 419-428.

Czerwiński, E., Borowy, P. \& Jasiak, B. (2006). Current guidelines for using physiotherapy for prevent falls. Ortopedia Traumatologia Rehabilitacja, 8(4), 380387.

Czerwiński, E., Kumorek, A., Milert, A. \& Borowy P. (2008). Causes of Falls in women in Krakow population. Ortopedia Traumatologia Rehabilitacja, 10(5), 429440.

Gąsienica-Walczak, B., Barczyński, B.J., Kalina, R.M. \& Kucio C. (2010). The effectiveness of two methods of teaching safe falls to physiotherapy students. Archives of Budo, 6(2), 63-71.

Groen, E.B., Smulders, E., Duysens, J., van Lankveld, W. \& Weerdesteyn, V. (2010). Could martial arts fall training be safe for persons with osteoporosis?: a feasibility study. BMC Research Notes, 2010, 3, 111. http://www.biomedcentral.com/17560500/3/111

Gruszczyński, K. \& Rutkowska, I. (2003). Specyfika wychowania fizycznego i sportu osób niewidomych, [Physical education anf sport blind people] [in:] Sozański, H., Perkowski, K., Śledziewski, D. (eds.) Kierunki doskonalenia treningu i walki sportowej, AWF Warszawa, 2003, 286-287. Jessup, G.M., Cornel, E. \& Bundy, A.C. (2010). The Treasure in Leisure Activities: Fostering Resilience in Young People Who Are Blind. Journal of Visual Impairment \& Blindness, 104, 7, 419-430.

Kalina, A., Kalina, R.M. \& Klukowski, K. (1998). Ćwiczenia unikania zderzeń i bezpiecznego upadku dla potrzeb rehabilitacji, [Exercises of avoid a collisions and safe falls in rehabilitation] Wychowanie Fizyczne i Zdrowotne, 45(1), 20-26.

Kalina, R.M., Barczyński, B., Jagiełło, W., Kruszewski, A., Przeździecki, B., Harasymowicz, J., Syska, J. \& Szamotulska K. (2008). Teaching of safe falling as most effective element of personal injury prevention in people regardless of gender, age and type of body build - the use of advanced information technologies to monitor the effects of education. Archives of Budo, 4, 82-90.

Kalina, R.M., Barczyński, B., Klukowski, K., Langfort, J. \& Gąsienica-Walczak, B. (2011). The method to evaluate the susceptibility of injuries during the fall validation procedure of the specific motor test. Archives of Budo, 7(4), 201-215.

Kalina, R.M., Kruszewski, A., Jagiełło, W. \& Włoch, G. (2003). Combat sports propaedeutics - basics of judo. AWF, Warsaw.

Li, F., Harmer, P., Fisher, K.J., McAuley, E., Chaumeton, N., Eckstrom, E. \& Wilson, N.L. (2005). Tai Chi and fall reductions in older adults: A randomized controlled trial. J Gerontol A Biol Sci Med Sci. 60(2), 187194.

Manduchi, R. \& Kurniawan, S. (2011). Mobility-related accidents experiences by people with visual impairment. Insight: Research \& Practice in Visual Impairment \& Blindness, 4(2), 44-53.

Odom, J.V., Odom, C.V. \& Leys MJ. (2011). Does improving vision reduce the risk of falls? A Review. Insight: Research \& Practice in Visual Impairment \& Blindness, 4(2), 92-99.

Patel, M., Gomez, S., Lush, D. \& Fransson, P.A. (2009). Adaptation and vision change the relationship between muscle activity of 
the lower limbs and body movement during human balance perturbations. Clin Neurophysiol, 120, 601-609

Patino, C.M., McKean-Cowdin, R., Azen, S.P., Allison, J.C., Choudhury, F. \& Varma, R. (2010). Central and peripheral visual impairment and the risk of falls and falls with injury. Ophthalmology, 117, 199-206.

Rose, D.J. (2008). Preventing falls among older adults: No "one size suits all" intervention strategy. Journal of Rehabilitation Research \& Development, 45(8), 1153-1166.

Rubenstein, L.Z., Josephson, K.R., Trueblood, P.R., Loy, S., Harker, J.O., Pietruszka, F.M. \& Robbins, A.S. (2000). Effects of a group exercise program on strength, mobility, and falls among fall-prone elderly men. $J$ Gerontol A Biol Sci Med Sci. 55(6), M317321.

Rutkowska, I., Bednarczuk, G. \& Skowroński W. (2010). Porównanie równowagi ciała $\mathrm{w}$ pozycji stojącej chłopców niewidomych i pełnosprawnych w wieku 6-16 lat. [Comparison of body balance in standing position of blind and sighted 6-16 years old boys] Postępy Rehabilitacji, 2, 29-35.

Rutkowska, I., Morgulec-Adamowicz, N. \& Skowroński, W. (2009). Porównanie budowy ciała, aktywności i sprawności fizycznej uczniów niewidomych i niedowidzących, [Comparison of body structure, activity and physical fitness of blind and Visual impairment pupils] [in:] Kuder A., Perkowski K., Śledziewski D. (red.) Proces doskonalenia treningu i walki sportowej, PTNKF Warszawa 2009, t. VI, 348-357.

Sipko, T., Skolimowski, T., Ostrowska, B. \& Anwajler J. (1997). Wpływ chwilowej i trwałe utraty kontroli wzrokowej położenia ciała $\mathrm{W}$ przestrzeni na proces regulacji równowagi ciała $\mathrm{w}$ pozycji stojącej. [Impact of lack of sight control in body balance regulation process] Fizjoterapia, 5(2), 11-15.

Skalska, A., Walczewska, J. \& Ocetkiewicz, T. (2003). Wiek, płeć i aktywność fizyczna osób zgłaszających upadki oraz okoliczności ich występowania. Rehabilitacja Medyczna, 7(3), 49-53.

Skelton, D.A., Kennedy, J. \& Rutherford O.M. (2002). Explosive power and asymmetry in leg muscle function in frequent fallers and non-fallers aged over 65. Age Ageing, 31, 119-125.

Tinetti, M.E. \& Williams, C.S. (1997). Falls, injures due to falls, and the risk of admission to a nursing home. The New England Journal of Medicine, 337(18), 1279-1284. 